\title{
PENGARUH SISTEM PERTANAMAN DAN GENOTIPE PADA PRODUKTIVITAS DAN VIABILITAS BENIH SORGUM (Sorghum bicolor (L.) Moench) PRA DAN PASCASIMPAN
}

\section{EFFECT OF CROPPING SYSTEMS AND GENOTYPES ON SORGUM SEED PRODUCTIVITY AND VIABILITY (Sorghum bicolor (L.) Moench) PRE AND POST}

\author{
Edi Susanto ${ }^{1 *}$, Eko Pramono ${ }^{2}$, Setyo Dwi Utomo ${ }^{2}$ dan M. Syamsoel Hadi ${ }^{2}$ \\ ${ }^{1}$ Jurusan Agroteknologi, ${ }^{2}$ Jurusan Agronomi dan Hortikultura, Fakultas Pertanian Universitas Lampung, \\ Bandarlampung, Indonesia \\ Email: edisusanto270595@gmail.com
}

* Corresponding Author, Diterima: 29 Sep. 2021 , Direvisi: 11 Nov. 2021 , Disetujui: 25 Des. 2021

\begin{abstract}
Sorghum crops include crops that are important after, rice, wheat, corn, and barley. The obstacle faced in cultivating sorghum plants in monoculture is the increasingly limited availability of land. This study aimed to determine the effect of the cropping system on the productivity and seed viability of four sorghum genotypes. The study was carried out on agricultural land in Karang Endah Village, Jati Agung District, South Lampung Regency $\left(5.28^{\circ}\right.$ latitude $105.27^{\circ}$ east longitude) with an altitude of 82.3 masl and at the Seed and Plant Breeding Laboratory, Faculty of Agriculture, University of Lampung from January 2019 to March 2020. The experimental design used was $2 \times 4$ factorial in a split plot with 3 blocks as replication. The main plot is a cropping system consisting of a monoculture system ( 1 1) and an intercropping system (s2). The subplots were genotypes consisting of GHP-29 (g1), GHP-3 (g2), Samurai-1 (g3), and GH-11 (g4). The cassava variety used was the UJ 3 variety. The results showed that the productivity of sorghum seeds harvested from monoculture was higher than that of intercropping. GHP-3 seed productivity was higher than GHP-29, Samurai-1 and GH-11. The viability of pre-stored and post-stored sorghum seeds for four and eight months showed no difference between sorghum seeds harvested from monoculture and intercropping. The viability of prestored and poststored seeds for four months showed that the GHP-3, Samurai-1, and GH11 genotypes were higher than the GHP-29 genotypes.
\end{abstract}

Keywords: Intercropping, seed productivity, seed viability, sorghum.

\section{ABSTRAK}

Tanaman sorgum termasuk tanaman yang penting setelah, padi, gandum, jagung, dan barley. Kendala yang dihadapi dalam budidaya tanaman tanaman sorgum secara monokultur adalah ketersediaan lahan yang makin terbatas. Penelitian ini bertujuan untuk mengetahui pengaruh sistem pertanaman pada produktivitas dan viabilitas benih empat genotipe sorgum. Penelitian dilaksanakan pada lahan pertanian di Desa Karang Endah, Kecamatan Jati Agung, Kabupaten Lampung Selatan $\left(5,28^{* \%}\right.$ LS 105,27*\% BT) dengan ketinggian 82,3 mdpl dan di Laboratorium Benih dan Pemuliaan Tanaman Fakultas Pertanian Universitas Lampung pada Januari 2019 sampai Maret 2020. Rancangan percobaan yang digunakan adalah faktorial $2 \times 4$ dalam split plot dengan 3 blok sebagai ulangan. Petak utama yaitu sistem pertanaman yang terdiri dari sistem pertanaman monokultur (s1) dan sistem pertanaman tumpangsari (s2). Anak petak yaitu genotipe yang terdiri dari GHP-29 (g1), GHP-3 (g2), Samurai-1 (g3), dan GH-11 (g4). Varietas Ubi kayu yang diguanakan adalah adalah varietas UJ 3. Hasil penelitian menunjukkan produktivitas benih sorgum yang dipanen dari pertanaman monokultur lebih tinggi dibandingkan pertanaman tumpangsari. Produktivitas benih GHP-3 lebih tinggi daripada GHP-29, Samurai-1 dan GH-11. Viabilitas benih sorgum prasimpan dan pascasimpan empat dan delapan bulan menunjukkan tidak berbeda antara benih sorgum yang dipanen dari pertanaman monokultur dan tumpangsari. Viabilitas benih prasimpan dan pascasimpan empat bulan menunjukkan genotipe GHP-3, Samurai-1, dan GH-11 lebih tinggi daripada genotipe GHP-29.

Kata kunci: Produktivitas benih, sorgum, tumpangsari, viabilitas benih. 


\section{PENDAHULUAN}

Sorgum merupakan tanaman yang berasal dari Afrika Selatan dengan 32 spesies. Tanaman ini asli dari daerah tropis dan subtropis di bagian pasifik tenggara dan Australia-Asia, umumnya tanaman sorgum dibudidayakan pada negara berkembang Asia dan Afrika. Secara global, spesies sorgum yang banyak dibudidaya adalah Sorghum bicolor, tanaman pangan ini termasuk tanaman yang penting setelah, padi, gandum, jagung, dan barley. Pada tahun 2012 di kawasan Asia, areal sorgum didominasi oleh India dengan luas areal panen sekitar 6,32 juta hektar (Susilowati dan Handewi, 2016). Menurut Iriani dan Makkulawu (2016), awal penyebaran sorgum di Indonesia dibawa oleh kolonial Belanda pada tahun 1925 dan mulai berkembang pada tahun 1940an.

Kendala yang dihadapi dalam meningkatkan produksi tanaman sorgum yaitu penggunaan benih yang kurang bermutu sehingga dalam menyediakan benih yang bermutu perlu dilakukan upaya mempertahankan viabilitas benih. Menurut Pramono et al. (2019) dalam mempertahankan mutu benih periode simpan benih perlu diperhatikan. Semakin lama benih disimpan benih akan mengalami proses kemunduran. Kemunduran benih menyebabkan permeabilitas membran yang meningkat karena adanya kegiatan enzim dalam metabolisme benih, peningkatan permeabilitas membran karena membran sel tidak utuh.

Penyediaan benih yang bermutu dapat meningkatkan produktivitas sorgum serta berkontribusi nyata terhadap penampilan fenotifik dan komponen hasil tanaman. Faktor yang berkaitan dengan mutu benih yaitu teknik produksi benih berkualitas, teknik mempertahankan kualitas benih yang telah didistribusikan, dan teknik deteksi atau mengukur kualitas benih (Subagio dan Aqil, 2013).

Kendala yang dihadapi dalam budidaya tanaman tanaman sorgum secara monokultur adalah keterbatasan lahan. Menurut Dewi dan Sarjana (2015) alih fungsi lahan di pengaruhi oleh beberapa faktor seperti faktor internal, faktor eksternal dan kebijakan pemerintah. Faktor internal karena masalah ekonomi pada masyarakat pertanian sehingga mereka melepaskan kepemilikan lahan. Faktor eksternal meliputi faktor yang terjadinya konversi lahan pertanian karena dinamika pertumbuhan perkotaan. Oleh sebab itu karena lahan yang semakin berkurang sedangkan kebutuhan pangan semakin meningkat maka harus dilakukan sistem pertanaman secara tumpang sari.
Tumpangsari merupakan suatu usaha menanam berbagai jenis tanaman pada satu areal lahan tanam dalam waktu yang bersamaan. Penanaman dengan cara tumpangsari bisa dilakukan pada jenis tanaman yang umurnya berbeda-beda. Di Indonesia ubi kayu menjadi makanan pokok ketiga setelah padi-padian dan jagung. Ubi kayu banyak dikembangkan di Provinsi Lampung, karena memiliki daya adaptasi yang luas serta risiko kegagalan panen kecil, dan toleran kekeringan. Keunggulan sistem tumpangsari antara sorgum dan ubikayu karena produksi tanaman ubi kayu UJ-5 yang tetap serta mendapat tambahan dari produksi sorgum (Rahmawati et al., 2014).

Klon ubi kayu UJ-5 atau kasetsart yang memiliki tinggi batang lebih rendah $>2,5 \mathrm{~m}$ dan umur panen 9-10 bulan lebih lama dibandingkan dengan klon UJ-3 (Thailand) yang memiliki tinggi tanaman 2,53,0 $\mathrm{m}$ dan umur panen 8-9 bulan (Balitkabi, 2016). Pada penelitian ini digunakan ubi kayu klon UJ-3 yang lebih genjah dan tinggi batang lebih tinggi daripada UJ-5. Permasalahan yang muncul adalah bagaimana produktivitas dan viabilitas benih sorgum yang dipanen dari tumpangsari dan monokultur.

Penelitian ini bertujuan untuk mengetahui produktivitas dan viabilitas benih dari empat genotipe sorgum yang dipanen dari pertanaman monokultur dan pertanaman tumpangsari sorgum dengan ubi kayu varietas UJ 3.

\section{BAHAN DAN METODE}

Penelitian ini dilakukan di Desa Karang Endah, Kecamatan Jati Agung, Kabupaten Lampung Selatan $\left(5,28^{\circ} \mathrm{LS} 105,27^{\circ} \mathrm{BT}\right)$ dengan ketinggian berkisar 82,3 $\mathrm{m}$ dpl dan di Laboratorium Benih dan Pemulian Tanaman Fakultas Pertanian, Universitas Lampung, Bandar Lampung, Indonesia. Waktu penelitian dilaksanakan pada Januari 2019 sampai dengan Maret 2020. Alatalat yang digunakan pada penelitian ini adalah pembajak tanah, golok, cangkul, knapsack sprayer, moisture tester, seed blower, seed counter, alat pengecambah benih tipe IPB 71-2A, meteran gulung, alat pengukur Daya Hantar Listrik (DHL), strapless, tali raffia, timbangan elektrik, pisau, dan plastik. Bahan-bahan yang digunakan dalam penelitian ini adalah benih sorgum genotype GHP-29, GHP-3, Samurai 1, GH-11, ubi kayu varietas UJ-3, pupuk NPK, pestisida aquades, plastic zip ukuran $6 \times 10 \mathrm{~cm}$, kertas merang, kertas $\mathrm{CD}$, plastik putih, karet gelang, dan label. 
Penelitian ini dilaksanakan dengan menggunakan rancangan percobaan split plot dan rancangan perlakuan faktorial $2 \times 4$ diacak secara lengkap 3 ulangan dalam 3 blok. Petak utama yaitu sistem pertanaman yang terdiri dari pola pertanaman yaitu monokultur $\left(\mathrm{s}_{1}\right)$ dan tumpangsari $\left(\mathrm{s}_{2}\right)$ dan genotipe sebagai anak petak yang terdiri dari 4 Genotipe, yaitu GHP-29 $\left(\mathrm{g}_{1}\right)$, GHP-3 $\left(\mathrm{g}_{2}\right)$, Samurai-1 $\left(\mathrm{g}_{3}\right)$, GH-11 $\left(\mathrm{g}_{4}\right)$. Homogenitas ragam antarperlakuan diuji dengan uji Bartlett sedangkan untuk menguji aditivitas data menggunakan $\mathrm{Uji}$ Tukey. Bila asumsi terpenuhi, data dianalisis ragam untuk melihat pengaruh antar perlakuan dan dilakukan pembanding nilai tengah dengan menggunakan Uji Beda Nyata Jujur (BNJ) untuk pembandingan nilai tengah antar perlakuanm yang masing-masing pada taraf nyata $5 \%$.

Pelaksanaan dalam penelitian ini meliputi persiapan benih, persiapan lahan pertanaman, penanaman (jarak tanam yaitu $15 \times 80 \mathrm{~cm}$ pada sistem pertanaman monokultur dan $15 \times 160 \mathrm{~cm}$ pada pertanaman tumpangsari), penentuan tanaman sampel, pemeliharaan, pemanenan, pengemasan benih sorgum, penyimpanan benih sorgum. Pengamatan produktivitas benih meliputi variabel bobot benih per malai, jumlah benih per malai, bobot 1000 benih dan pengamatan viablitas benih meliputi variabel kecambah normal total, kecepatan perkecambahan, kecambah normal kuat. Viabilitas benih dievalusi dengan uji perkecambahan benih. Uji perkecambahan dilakukan dengan menanam 50 butir benih sorgum di kertas merang yang telah dilembabkan lalu ditutup dengan kertas merang lagi kemudian didirikan dan diletakkan dalam germinator tipe IPB 73 2A/2B. Kecambah diamati selama 5 hari dimulai dari dua hari setelah tanam. Variabel yang diamati adalah kecambah nomal total, kecepatan perkecambahan, dan kecambah normal kuat. Kecambah normal total dihitung dengan rumus (ISTA, 2010):

$$
\mathrm{KNT}=(\Sigma \mathrm{KN} i / 50) \times 100 \%
$$

dengan $\mathrm{KNT}=$ Kecambah Normal Total (\%); $\Sigma \mathrm{KN} i=$ Jumlah kecambah normal yang tumbuh pada hari ke 2 sampai hari 5. Kecepatan perkecambahan (KP) dapat dinyatakan dengan rumus (Copeland dan Donald, 2001) sebagai berikut:

$$
\begin{aligned}
& \mathrm{KP}=\frac{K N 1}{d 1}+\frac{K N 2}{d 2}+\frac{K N 3}{d 3}+\cdots+\frac{K N n}{d n} \\
& \mathrm{KP}=\text { Kecepatan Perkecambahan }(\% / \text { hari }),
\end{aligned}
$$
$\mathrm{KN}=$ Persen Kecambah Normal (\%), $\mathrm{d}=$ hari pengamatan, $\mathrm{n}=$ hari terakhir pengamatan.
Kecambah normal kuat dinyatakan dengan rumus sebagai berikut:

$\mathrm{KNK}=\frac{\sum \text { Kecamba } h \text { Normal Kuat yang dihasilkan }}{\text { total beni } h \text { yang ditanam }} \times 100 \%$

\section{HASIL DAN PEMBAHASAN}

\subsection{Pengaruh Sistem Pertanaman dan Empat Genotipe Sorgum pada Produktivitas Sorgum}

Perlakuan sistem pertanaman monokultur menunjukkan nilai bobot benih per malai dan jumlah benih per malai yang berbeda dengan sistem pertanaman tumpangsari (Tabel 1). Bobot benih per malai pada sistem pertanaman monokultur $(27,50$ g) lebih tinggi daripada sistem pertanaman tumpangsari $(22,52 \mathrm{~g})$. Jumlah benih per malai pada sistem pertanaman monokultur (612,32 butir) lebih tinggi daripada sistem pertanaman tumpangsari (263,21 butir). Perlakuan genotipe sorgum berpengaruh nyata terhadap bobot benih per malai dan jumlah benih per malai. Genotipe GHP-3 pada variabel bobot benih per malai tidak berbeda dengan GHP-29 namun berbeda nyata dengan Samurai-1 dan GH-11. Pada variabel jumlah benih per malai genotipe GHP-3 tidak berbeda nyata dengan GHP29 dan Samurai-1 tetapi berbeda nyata dengan GH-11.

Sistem pertanaman monokultur menunjukkan nilai kecepatan perkecambahan,kecambah normal total dan kecambah normal kuat yang tidak berbeda dengan sistem pertanaman tumpangsari (Tabel 2). Perlakuan genotipe sorgum berpengaruh nyata terhadap kecepatan perkecambahan, kecambah normal total dan kecambah normal kuat. Genotipe GHP-3 menunjukkan nilai kecepatan perkecambahan $(35 \% /$ hari) tidak berbeda dengan Samurai-1 (34\%/hari) dan GH-11 (34\%/hari) namun berbeda dengan GHP-29 (12\%/hari). Genotipe GH-11 menunjukkan kecambah normal total $(80 \%)$ tidak berbeda dengan genotipe GHP3 (78\%), Samurai-1 (77\%), namun berbeda dengan GHP-29 (18 \%). Genotipe GHP-3 menunjukkan nilai kecambah normal kuat (74\%) tidak berbeda dengan Samurai-1 (62 \%), GH-11 (64 \%) namun berbeda dengan GHP-29 (13\%).

\subsection{Viabilitas Benih Sorgum Pascasimpan Empat Bulan}

Perlakuan sistem pertanaman monokultur menunjukkan nilai kecepatan perkembahan, 
Tabel 1. Pengaruh Sistem Pertanaman dan Empat Genotipe Sorgum pada Produktivitas Sorgum (Sorghum bicolor [L.] Moench).

\begin{tabular}{|c|c|c|c|c|}
\hline \multirow{3}{*}{ Perlakuan } & \multicolumn{4}{|c|}{ Variabel yang diamati } \\
\hline & \multirow{2}{*}{$\begin{array}{c}\text { Bobot } 1000 \text { Butir } \\
(\mathrm{g})\end{array}$} & \multirow{2}{*}{$\begin{array}{l}\text { Bobot Benih } \\
\text { Per malai (g) }\end{array}$} & \multicolumn{2}{|c|}{ Jumlah Benih Per malai } \\
\hline & & & (Trans $\log (\mathrm{x}))$ & Detrans \\
\hline \multicolumn{5}{|l|}{ Pertanaman $(\mathrm{P})$} \\
\hline Monokultur & $33,02 \mathrm{a}$ & $27,50 \mathrm{a}$ & $2,74 \mathrm{a}$ & 612,32 \\
\hline Tumpangsari & $30,41 \mathrm{a}$ & $22,52 \mathrm{~b}$ & $2,39 \mathrm{~b}$ & 263,21 \\
\hline BNJ 5\% & 9,14 & 2,89 & \multicolumn{2}{|c|}{0,30} \\
\hline \multicolumn{5}{|l|}{ Genotipe(G) } \\
\hline GHP-29 & $31,17 \mathrm{a}$ & $24,91 \mathrm{ab}$ & $2,59 \mathrm{a}$ & 436,00 \\
\hline GHP-3 & $33,13 \mathrm{a}$ & $31,21 \mathrm{a}$ & $2,75 \mathrm{a}$ & 654,30 \\
\hline Samurai-1 & $35,07 \mathrm{a}$ & $23,09 \mathrm{~b}$ & $2,57 \mathrm{a}$ & 415,08 \\
\hline GH-11 & 27,49 a & $20,83 \mathrm{~b}$ & $2,34 \mathrm{~b}$ & 245,67 \\
\hline BNJ 5\% & 9,29 & 8,04 & \multicolumn{2}{|c|}{0,26} \\
\hline
\end{tabular}

Keterangan: Angka-angka sekolom yang diikuti huruf yang sama tidak berbeda menurut uji BNJ 5\%.

Tabel 2. Pengaruh Sistem Pertanaman dan Empat Genotipe Sorgum pada Viabilitas Benih Prasimpan

\begin{tabular}{|c|c|c|c|c|c|}
\hline \multirow{3}{*}{ Perlakuan } & \multicolumn{5}{|c|}{ Variabel yang diamati } \\
\hline & \multirow[b]{2}{*}{ PKP (\%) } & \multicolumn{2}{|c|}{ KNT } & \multicolumn{2}{|c|}{ PKNK } \\
\hline & & $\begin{array}{c}\text { Trans Arsin } \\
\sqrt{x}\end{array}$ & Detrans & Trans $\operatorname{Arsin} \sqrt{x}$ & Detrans \\
\hline \multicolumn{6}{|l|}{ Pertanaman $(\mathrm{P})$} \\
\hline Monokultur & $29,69 \mathrm{a}$ & $52,74 \mathrm{a}$ & 62,50 & $46,06 \mathrm{a}$ & 52,83 \\
\hline Tumpangsari & $29,07 \mathrm{a}$ & $52,47 \mathrm{a}$ & 64.33 & $47,66 \mathrm{a}$ & 54,67 \\
\hline $1 \mathrm{BNJ} 5 \%$ & 8,06 & \multicolumn{2}{|c|}{17,02} & \multicolumn{2}{|c|}{6,96} \\
\hline \multicolumn{6}{|l|}{ Genotipe (G) } \\
\hline GHP-29 & $12,60 \mathrm{~b}$ & $21,74 \mathrm{~b}$ & 18,00 & $21,59 \mathrm{~b}$ & 13,67 \\
\hline GHP-3 & $35,67 \mathrm{a}$ & $62,61 \mathrm{a}$ & 78,33 & $60,08 \mathrm{a}$ & 74,33 \\
\hline Samurai-1 & $34,28 \mathrm{a}$ & $62,22 \mathrm{a}$ & 77,33 & $52,40 \mathrm{a}$ & 62,67 \\
\hline GH-11 & $34,96 \mathrm{a}$ & $63,86 \mathrm{a}$ & 80,00 & $53,37 \mathrm{a}$ & 64,33 \\
\hline BNJ 5\% & 9,93 & \multicolumn{2}{|c|}{16,96} & \multicolumn{2}{|c|}{8,37} \\
\hline
\end{tabular}

Keterangan: Angka-angka sekolom yang diikuti huruf yang sama tidak berbeda menurut uji BNJ 5\%. PKP $=$ Persentase Kecepatan Perkecambahan, KNT = Kecambah Normal Total, PKNK= Persentase Kecambah Normal Kuat

kecambah normal total dan kecambah normal kuat yang tidak berbeda dengan sistem pertanaman tumpangsari (Tabel 3). Perlakuan genotipe sorgum berpengaruh nyata terhadap kecepatan perkecambahan, kecambah normal total dan kecambah normal kuat. Genotipe Samurai-1 menunjukkan nilai kecepatan perkecambahan (34 $\% /$ hari) tidak berbeda dengan GHP-3 (32\%/hari) dan GH-11 (33\%/hari) namun berbeda dengan GHP-29 (27\%/hari). Genotipe Samurai-1 menunjukkan nilai kecambah normal total $(80 \%)$ tidak berbeda dengan GHP-3 (70 \%), GH-11 (75 \%) namun berbeda dengan GHP-29 (52\%). Samurai-1 menunjukkan nilai kecambah normal kuat $(78,67 \%)$ tidak berbeda dengan GHP-3 (67 $\%)$, GH-11 (63 \%) namun berbeda dengan GHP$29(43 \%)$.

\subsection{Viabilitas Benih Sorgum Pascasimpan Delapan Bulan}

Perlakuan sistem pertanaman monokultur menunjukkan nilai kecepatan perkembahan, kecambah normal total dan kecambah normal kuat yang tidak berbeda dengan sistem pertanaman tumpangsari (Tabel 4). Perlakuan genotipe sorgum berpengaruh nyata terhadap kecepatan perkecambahan,kecambah normal total dan kecambah normal kuat. Genotipe Samurai-1 menunjukkan kecepatan perkecambahan paling tinggi (30\%/hari) dan berbeda nyata dengan GHP29 (25\%/hari), GHP-3 (26\%/hari) dan GH-11 (25 $\%$ /hari). Genotipe GH-11 menunjukkan nilai kecambah normal total nyata lebih rendah (52\%) daripada Samurai-1 (77\%), tetapi tidak berbeda 
nyata dengan GHP-29 (57 \%). Samurai-1 menunjukkan nilai kecambah normal kuat (70 \%) berbeda nyata dengan GH-11 (50\%) tetapi tidak berbeda dengan GHP-29 (51\%) dan GHP-3 $(60 \%)$.

\subsection{Pembahasan}

Hasil penelitian menunjukkan bahwa pengaruh sistem pertanaman monokultur dan tumpangsari sorgum-ubi kayu menunjukkan hasil yang berbeda nyata pada produktivitas yang ditunjukkan oleh variabel bobot benih per malai dan jumlah benih per malai. Bobot benih per malai sistem pertanaman monokultur $(27,50 \mathrm{~g})$ lebih tinggi dari sistem pertanaman tumpangsari $(22,52 \mathrm{~g})$ dengan selisih $4,98 \mathrm{~g}$ (Gambar 1). Jumlah benih per malai pada sistem pertanaman monokultur (612,32 butir) lebih tinggi dari sistem pertanaman tumpangsari $(263,21$ butir) yang memiliki selisih 349,11 butir (Gambar 2). Produktivitas sorgum pada sistem pertanaman monokultur genotipe GHP-29 ( 4,15 ton/ha), GHP3 (5,20 ton/ha), Samurai-1 (3,85 ton/ha), dan GH$11(3,47$ ton/ha) lebih tinggi dari produktivitas sorgum sistem pertanaman tumpangsari genotipe
GHP-29 (2,08 ton/ha), GHP-3 (2,60 ton/ha), Samurai-1 (1,92 ton/ha), dan GH-11 (1,74 ton/ha). Pada variabel bobot benih per malai genotipe GHP3 berbeda nyata dengan genotipe Samurai 1 dan GH-11 tetapi tidak berbeda nyata dengan genotipe GHP 29. GHP-3 memiliki berat $31,21 \mathrm{~g}$ yang lebih tinggi dibandingkan dengan genotipe lainnya. Genotipe GHP-3 menjanjikan untuk dikembangkan sebagai sorgum biji karena memiliki hasil fotosintat cukup tinggi dengan indek panen (IP) 0,68 (Hadi et al., 2016).

Hasil menunjukkan bahwa pengaruh sistem pertanam tidak berbeda nyata pada semua variabel viabilitas benih prasimpan. Berdasarkan uji BNJ pengaruh perlakuan genotipe GHP-29 berbeda nyata terhadap semua variabel yang diamati. Genotipe GHP-29 menunjukan hasil terendah pada variabel kecepatan perkecambahan (12\%), kecambah normal total (18\%) dan kecambah normal kuat (13\%) jika dibandingkan dengan genotipe lainnya (Tabel 2). Perkecambahan yang rendah diduga benih yang masih dorman yang didukung dengan tingginya persentase benih tidak berkecambah pada bulan ke nol sebesar $81 \%$ dibandingkan dengan persentase benih tidak

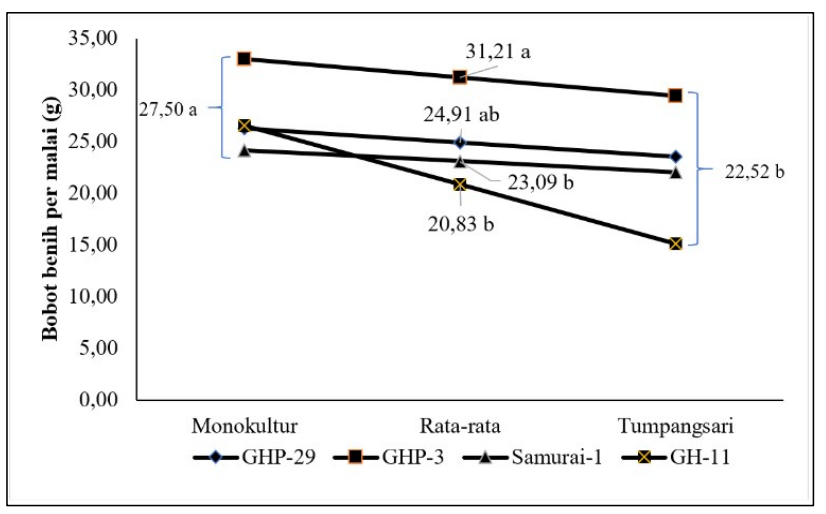

Gambar 1. Bobot Benih Per Malai (g)

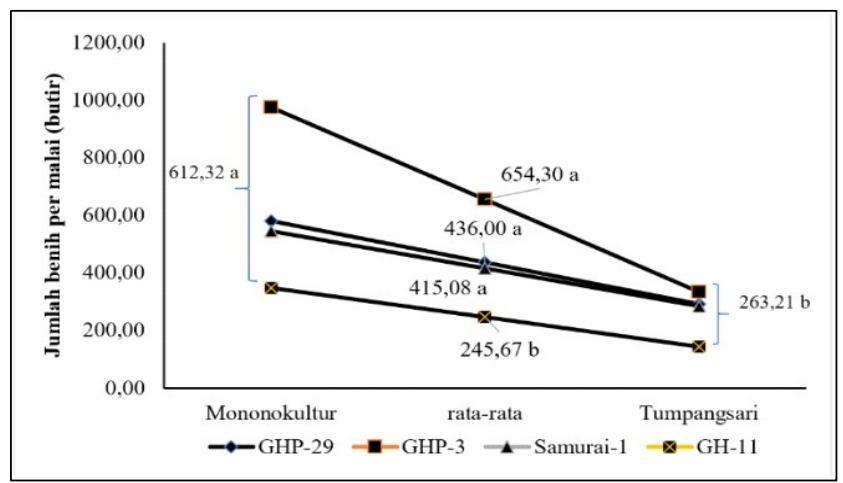

Gambar 2. Jumlah Benih Per Malai (butir) 
berkecambah pada bulan ke empat sebesar $46 \%$. Hal ini dikarenakan sifat benih sorgum merupakan benih ortodoks (Utamako et. al., 2015). Menurut Yuniarti (2016) benih ortodok adalah benih yang dapat dikeringkan sampai kadar air rendah dan dapat disimpan dalam waktu lama pada suhu dan kelembapan yang rendah. Menurut Widajati (2014), dormansi benih adalah kondisi benih hidup yang tidak berkecambah sampai batas akhir pengamatan walaupun kondisi lingkungan yang optimum untuk perkecambahan. Benih sorgum tersebut dormansi dapat disebabkan oleh faktor fisik maupun fisiologis, menurut Kartika et.al. (2015) pematahan dormansi dapat mengunakan Menurut Anggraini et al. (2018) pemberian senyawa KNO3 mampu meningkatkan pertumbuhan tanaman, karena dapat mengaktifkan hormon giberelin untuk merombak enzim amilase. Enzim amilase mengubah amilum menjadi glukosa. Glukosa akan membentuk ATP yang diperlukan untuk pemanjangan akar. Menurut Nasrulloh et al. (2020), benih sorgum masih memiliki viabilitas yang baik selama penyimpanan 12 bulan.

Pada viabilitas benih pascasimpan empat bulan, sorgum genotipe GHP-29 semakin meningkat perkecambahannya yang ditunjukkan dengan meningkatnya persentase perkecambahan pada kecepatan perkecambahan (27\%), kecambah normal total (52 \%) dan kecambah normal kuat (43\%) (Tabel 3) yang telah dimulainya kembali proses metabolisme dan pertumbuhan struktur penting embrio yang sebelumnya tertunda, ditandai dengan muncunya struktur tersebut menembus kulit benih. Menurut Siregar (2003) struktur kulit biji yang keras dapat menghalangi pertukaran gas dan imbibisi air dalam proses perkecambahan. Genotipe Samurai-1 berkecambah lebih tinggi pada variabel

Tabel 3. Pengaruh Sistem Pertanaman dan Empat Genotipe Sorgum pada Viabilitas Benih Pascasimpan Empat Bulan.

\begin{tabular}{lccc}
\hline \multirow{2}{*}{ Perlakuan } & \multicolumn{3}{c}{ Variabel yang diamati } \\
\cline { 2 - 4 } & PKP (\%) & KNT (\%) & PKNK (\%) \\
\hline Pertanaman (P) & $31,66 \mathrm{a}$ & $66,33 \mathrm{a}$ & $51,87 \mathrm{a}$ \\
Monokultur & $32,76 \mathrm{a}$ & $73,17 \mathrm{a}$ & $49,33 \mathrm{a}$ \\
Tumpangsari & 8,77 & 17,59 & 12,76 \\
\hline BNJ 5\% & & & $43,67 \mathrm{~b}$ \\
\hline Genotipe (G) & $27,80 \mathrm{~b}$ & $52,67 \mathrm{~b}$ & $67,33 \mathrm{a}$ \\
GHP-29 & $32,70 \mathrm{ab}$ & $70,00 \mathrm{a}$ & $78,67 \mathrm{a}$ \\
GHP-3 & $34,53 \mathrm{a}$ & $80,67 \mathrm{a}$ & $63,33 \mathrm{a}$ \\
Samurai-1 & $33,81 \mathrm{a}$ & $75,67 \mathrm{a}$ & 15,55 \\
GH-11 & 5,72 & 16,29 & P
\end{tabular}

Keterangan: Angka-angka sekolom yang diikuti huruf yang sama tidak berbeda menurut uji BNJ 5\%. PKP = Persentase Kecepatan Perkecambahan, KNT = Kecambah Normal Total, PKNK= Persentase Kecambah Normal Kuat

Tabel 4. Pengaruh Sistem Pertanaman dan Empat Genotipe Sorgum pada Viabilitaas Benih Pascasimpan Delapan Bulan.

\begin{tabular}{lccc}
\hline \multirow{2}{*}{ Perlakuan } & \multicolumn{3}{c}{ Variabel yang diamati } \\
\cline { 2 - 3 } & PKP $(\%)$ & KNT $(\%)$ & PKNK $(\%)$ \\
\hline Pertanaman (P) & $26,36 \mathrm{a}$ & $58,67 \mathrm{a}$ & $46,27 \mathrm{a}$ \\
Monokultur & $27,64 \mathrm{a}$ & $65,67 \mathrm{a}$ & $46,80 \mathrm{a}$ \\
Tumpangsari & 8,15 & 17,40 & 3,13 \\
\hline BNJ 5\% & & & $51,00 \mathrm{ab}$ \\
\hline Genotipe (G) & $25,45 \mathrm{~b}$ & $57,00 \mathrm{ab}$ & $60,67 \mathrm{ab}$ \\
GHP-29 & $26,54 \mathrm{~b}$ & $62,33 \mathrm{ab}$ & $70,33 \mathrm{a}$ \\
GHP-3 & $30,26 \mathrm{a}$ & $77,00 \mathrm{a}$ & $50,67 \mathrm{~b}$ \\
SAMURAI-1 & $25,74 \mathrm{~b}$ & $52,33 \mathrm{~b}$ & 11,45 \\
GH-11 & 3,14 & 21,94 & \\
\hline BNJ 5\% & & & \\
\hline
\end{tabular}

Keterangan: Angka-angka sekolom yang diikuti huruf yang sama tidak berbeda menurut uji BNJ 5\%. PKP = Persentase Kecepatan Perkecambahan, KNT = Kecambah Normal Total, $\mathrm{PKNK}=$ Persentase Kecambah Normal Kuat 


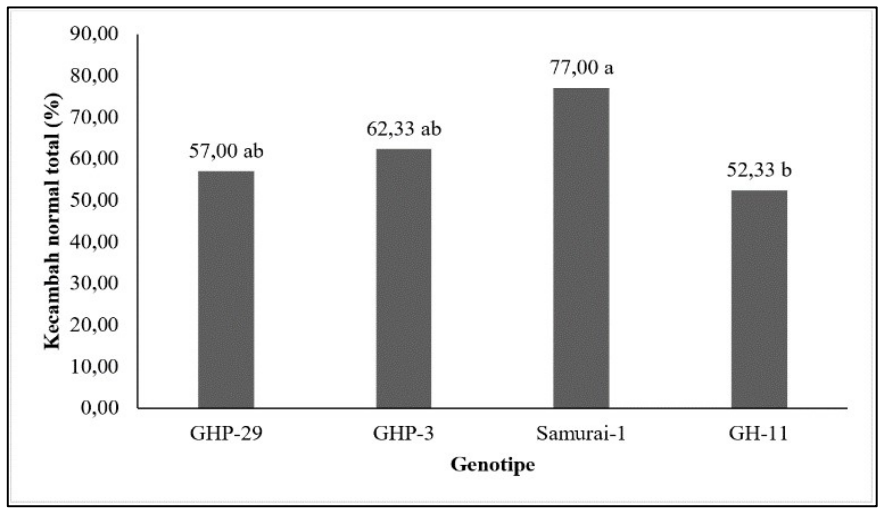

Gambar 3. Kecambah Normal Total (\%) pada Pascasimpan Delapan Bulan

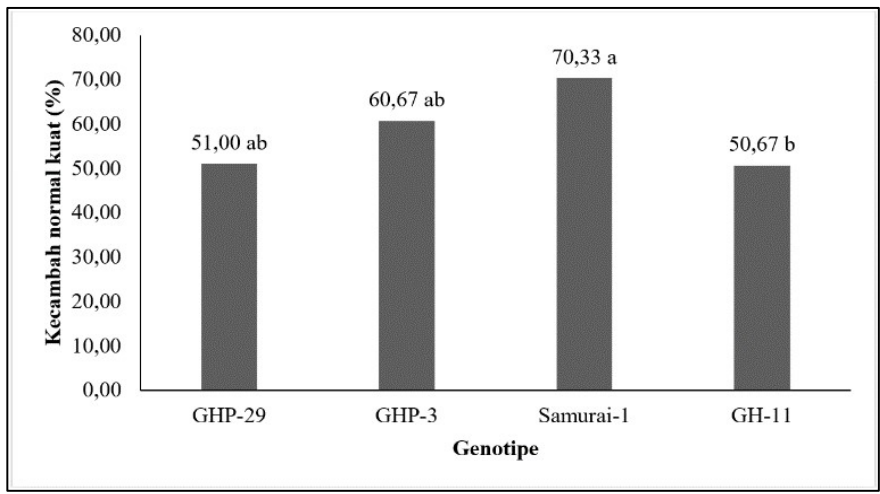

Gambar 4. Kecambah Normal Kuat (\%) pada Pascasimpan Delapan Bulan

kecepatan perkecambahan (34\%), kecambah normal total $(80 \%)$, dan kecambah normal kuat (78 \%). Menurut Rini et al. (2005) suatu benih dikatakan mempunyai viabilitas yang baik apabila persentase perkecambahannya lebih dari $80 \%$.

Hasil penelitian menunjukkan viabilitas benih pascasimpan delapan bulan pada variabel kecepatan perkecambahan dan kecambah normal total varietas samurai-1 berbeda nyata dibandingan dengan genotipe GHP-29, GHP-3 dan GH-11. Varietas Samurai-1 menunjukkan hasil tertinggi yaitu $30 \%$ pada variabel kecepatan perkecambahan (Tabel 4) hal ini berarti varietas Samurai-1 memiliki vigor yang lebih baik dibandingkan dengan genotipe lainnya. Pada variabel kecambah normal total Genotipe GH-11 berbeda dengan Samurai-1 tetapi tidak berbeda dengan GHP-29, dan GHP-3 (Gambar 3). Pada variabel kecambah normal kuat Samurai-1 berbeda nyata dengan GHP-29, GHP3, dan GH-11 (Gambar 4). Benih sorgum yang disimpan pada empat bulan memiliki vigor yang lebih baik dibandingkan dengan penyimpanan delapan bulan. Persentase perkecambahan benih sorgum penyimpanan delapan bulan mengalami penurunan pada variabel kecepatan perkecambahan, kecambah normal total, dan kecambah normal kuat. Penurunan persentase perkecambahan benih disebabkan karena semakin lamanya benih yang disimpan sehingga viabilitas benih menurun. Menurut Pramono et al. (2019) lama simpan pada penyimpanan benih sorgum mempengaruhi kemunduran dan vigor benih, benih yang disimpan pada lama simpan yang lebih lama dapat meningkatkan persentase benih rusak. Pada penelitian ini pengaruh masing-masing genotipe sorgum yang berbeda nyata mengalami kemunduran yang dapat disebabkan karena perbedaan faktor genetik genotipe sorgum. Menurut Nasrulloh et al. (2020) faktor genetik tanaman sorgum menunjukkan respon yang berbeda antar genotipe pada parameter kemunduran benih selama penyimpanan.

\section{KESIMPULAN}

Produktivitas benih sorgum sistem pertanaman monokultur lebih tinggi daripada sistem pertanaman tumpangsari pada variabel bobot benih per malai 
(27,50 g) dan jumlah benih per malai (612 butir). Pada viabilitas benih pra dan pascsimpan 4 dan 8 bulan tidak berbeda nyata antara sistem pertanaman monokultur maupun tumpangsari. Produktivitas benih sorgum genotipe GHP-3 variabel bobot benih per malai $(31,21 \mathrm{~g})$ dan jumlah benih per malai (654 butir ) lebih tinggi daripada GHP-29, Samurai-1, dan GH-11. Viabilitas benih pra dan pascasimpan 4 bulan genotipe GHP-29 lebih rendah daripada GHP-3, samurai-1, dan GH-11 dan pada pascsimpan 8 bulan genotipe Samurai-1 lebih tinggi daripada tiga genotipe lainnya.

\section{DAFTAR PUSTAKA}

Anggraini, P. D., Tundjung, T., Handayani, Yulianty, dan Zulkifli. Pengaruh pemberian senyawa KNO3 (kalium nitrat) terhadap pertumbuhan kecambah sorgum (Sorghum bicolor (L.) Moench). Jurnal Biologi Eksperimen dan Keanekaragaman Hayati. 5 (1): 37-42.

[Balitkabi] Balai Penelitian Tanaman Aneka Kacang dan Umbi. 2016. Deskripsi Varietas Unggul Ubi Kayu 1978-2016. http:// balitkabi.litbang.pertanian.go.id/wpcontent/uploads/2016/09/ubikayu.pdf. Diakses pada 22 November 2019

Dewi, I. L. dan I. M. Sarjana. 2015. Faktor-Faktor Pendorong Alihfungsi Lahan Sawah Menjadi Lahan Non-Pertanian. Jurnal Manajemen Agribisnis. 3 (2).

Hadi, M. S., M. Kamal., K. Setiawan., A. Kurniawan., dan Z. Purnawan. 2016. Evaluasi Vegetatif dan Generatif beberapa Genotipe Sorgum [Sorghum bicolor (L.) Moench] di Lahan Kering. Prosiding Seminar Nasional dan Kongres Perhimpunan Agronomi Indonesia 2016. Makalah.

Iriani, R. N., dan A. T. Makkulawu. 2016. Asal Usul dan Taksonomi Tanaman Sorgum balitsereal.litbang.pertanian.go.id/wpcontent/uploads/2016/11/nenis.pdf. Diakses pada 29 Oktober 2019.

Kartika, Surahman, M., dan Susanti, M. 2015. Pematahan dormansi benih kelapa sawit (Elaeis guineensis Jacq.) menggunakan KNO3 dan skarifikasi. Jurnal Pertanian dan Lingkungan. 8 (2): 48-55.
Nasrulloh, M. Z., E. Pramono, Agustiansyah, dan Y. Nurmiaty. 2020. Pengaruh suhu dan genotipe pada viabilitas benih sorgum (sorghum bicolor [L.] Moench. ) pasca simpan 12 bulan. J. Agrotek Tropika. 8 (1): 67-75.

Nurussintani, W., Damanhuri, dan S. L. Purnamaningsih. 2013. Perlakuan pematahan dormansi terhadap daya tumbuh benih 3 varietas kacang tanah (Arachis hypogaea). Jurnal Produksi Tanaman. 1 (1) : 86-93.

Pramono, E., M. Kamal., K. Setiawan., dan M. A. Tantia. 2019. Pengaruh lama simpan dan suhu ruang penyimpanan pada kemunduran dan vigor benih sorgum (Sorghum bicolor [L.] Moench.) varietas samurai-1. J. Agrotek Tropika. 7(3): 383-389.

Rahmawati, A., M. Kamal., dan Sunyoto. 2014. Respon beberapa genotipe sorgum (Sorgum bicolor [L.] Moench) terhadap sistem tumpangsari dengan ubi kayu (Manihot esculenta Crantz.). J. Agrotek Tropika. 2(1): 25-29.

Rini, D. S., Mustikoweni, dan Surtiningsih, T. 2005. Respon perkecambahan benih sorgum [Sorghum bicolor (L.) Moench] terhadap perlakuan osmoconditioning dalam mengatasi cekaman salinitas. Berita Biologi. 7(6): 307-313.

Siregar, B. L. 2003. Andaliman (Zanthoxylum acanthopodium DC.) di Sumatera Utara: Deskripsi dan Perkecambahan. Hayati. 10 (1) : 38-40.

Subagio, H dan M. Aqil. 2013. Pengembangan produksi sorgum di indonesia. Seminar nasional Inovasi Teknologi Pertanian. Balai Penelitian Tanaman Serealia

Utamako, A., Agustiansyah., dan M. Kamal. 2015. Pengaruh jenis kemasan terhadap viabilitas benih tiga varietas sorgum (Sorghum bicolor (L.) Moench) pada suhu ruang simpan berbeda. Jurnal Penelitian Pertanian Terapan. 15 (2): 81-89.

Widajati, E. 2014. Dasar Ilmu dan Teknologi Benih. PT Penerbit IPB Press. Bogor. hlm 129

Yuniarti, N,. Y. Bramasto., D. F. Jam'an., D. J. Sudrajat. 2016. Teknologi Perbenihan 10 Jenis Tanaman Hutan Andalan. PT Penerbit IPB Press. Bogor. 